\title{
Clarification of Pharmaceutical Wastewater with Moringa Oleifera: Optimization Through Response Surface Methodology
}

\author{
Iva Rustanti Eri', Wahyono Hadi ${ }^{*}$, Agus Slamet ${ }^{2}$ \\ 1 Department of Environmental Health, Politeknik Kesehatan Kementerian Kesehatan, Surabaya 60282, \\ Indonesia \\ 2 Department of Environmental Engineering, Institut Teknologi Sepuluh Nopember, Surabaya 60111, Indonesia \\ * Corresponding author's e-mail: wahyono.its@gmail.com
}

\begin{abstract}
Herbal pharmaceutical industrial wastewater contains a high amount of suspended solids and alkaline $(\mathrm{pH}>8)$; therefore it requires approprite coagulant and flocculant compounds for its wastewater treatment. The most widely used flocculant is a synthetic that has certain problems such as non-biodegradability and releases of toxic residual monomers. The use of eco-friendly flocculants as alternative materials for conventional flocculant in water and wastewater treatments is increasing. Numerous factors influence the performance of coagulation-flocculation process, such as coagulant dosage, flocculant dosage, initial potential of hydrogen $(\mathrm{pH})$ and velocity gradient of coagulation-flocculation. The main aim of this research is to evaluate the capability and effectiveness of Moringa oleifera extract for removal of suspended solid in herbal pharmaceutical industry. A coagulation-flocculation test was done by performing jar test at various speeds, according to the variation of the conducted treatment research. In this study, response surface methodology (RSM) approach was used to optimize the concentration of coagulant dosage, flocculant dosage and flocculation velocity gradient $(\mathrm{G})$, and the results were measured as maximum percentage of suspended solid removal. The wastewater used in this research originally came from the inlet of herbal pharmaceutical industry wastewater treatment plant, which was collected over 3 days. The wastewater has a total suspended solids of more than $1250 \mathrm{mg} / \mathrm{L}$, and was alkaline ( $\mathrm{pH} 9-10)$. The moringa extract was made from the extraction of a fat free moringa powder with a salt solution in a certain ratio. The percentage removal of suspended solid was $93.42-99.54 \%$. The final results of the analysis of response surface showed that the variables of flocculant dosage and the flocculation velocity gradient $(G)$ have a huge impact on the amount of suspended solid removal, compared with the coagulant dosage. The model generated from the response analysis is a quadratic model. The optimum point of the removal suspended solid quadratic model is at $10.6566 \mathrm{mg} / \mathrm{L}$ alum dosage, $13.8185 \mathrm{ml} / \mathrm{L}$ Moringa oleifera extract dosage, and $G$ velocity of flocculation $84.845 \mathrm{sec}^{-1}$.
\end{abstract}

Keywords: flocculant, Moringa oleifera, response surface methodology

\section{INTRODUCTION}

In most cases, the source of herbal pharmaceutical industry wastewater disposal came from its raw material and production tank washing processes. The wastewater contains snuff-colored organic chemicals. The organic substance content, which was measured as Chemical Oxygen Demand (COD) amounted to $3000-6000 \mathrm{mg} / \mathrm{L}$ (Krzemińska et al., 2015). Wastewater treatment processes that were utilized in herbal pharmaceutical industry are coagulation-flocculation system, clarification with lamella, sedimentation and filtration. The coagulation-flocculation sys- tem uses inorganic coagulants: Aluminum Sulfate (Alum) and Polyaluminum Chloride (PAC) (Bratby, 2016; Suopajärvi et al. 2013; Wang et al. 2014; Irfan et al. 2017).

In certain studies, inorganic coagulant like Aluminum Sulfate (Alum) has been widely used without any flocculants (Dassanayake et al. 2015; Subramonian et al. 2014). Aluminum Sulfate will carry out rapid hydrolyzing inside aqueous solution to form cationic species; further on, it will be adsorbed with negative charged colloid particles, creating microfloc formation. Smaller microfloc has low solidity that will be disintegrated if exposed by physical intensity. Low efficiency 
process and metal residue found in supernatant shows the relevancy of flocculants applied in the coagulation-flocculation process (Lee et al. 2014).

Inorganic flocculants which are commonly used in wastewater treatment are synthetics, such as poly-acrylamides, poly-acrylic, polysryrene sulfonic acids and its derivatives. These flocculants are mostly linier water-soluble polymers with repeating units of various monomers, high molecular weight and can be ionic as polyelectrolyte or non-ionic. Flocculants synthetics caused some environmental and health issues regarding their non-biodegradable characteristic, and metal residue occurrence in water (Shak and Wu 2014; Bratby, 2016). Thus, the use of eco-friendly flocculants as alternative materials for conventional flocculants in water and wastewater treatments is increasing (Bhuptawat et al. 2007).

Many efective factors influence the performance of the coagulation-flocculation process, such as coagulant dosage, flocculant dosage, initial potential of hydrogen $(\mathrm{pH})$ and velocity gradient of coagulation-flocculation. In previous studies on coagulation-flocculation, in terms of turbidity removal, optimization is mostly done with varying one factor while others remain constant (Ghebremichael et al. 2005; Hendrawati et al. 2016). This approach will surely consume more time and energy, which also leads to inaccurate optimization as regards the factor interaction. In order to overcome this issues, response surface methodology (RSM) can be considered as the right approach as it accounts for the impact from individual factors and their interactions. RSM consists of statistical and mathematic techniques which provide comprehension in mathematic correlation between effective factors. Thus, the RSM methodology will be effectively used to optimize coagulation-flocculation process in wastewater treatment system (Harfouchi et al. 2016; Nourani et al. 2016).

The studies on Moringa oleifera's competence in water and wastewater treatment process had been undertaken by numerous scholars (Baptista et al. 2015, 2017; Santos et al. 2016; Amante et al. 2016; Pavankumar et al. 2014; Garde et al. 2017). A research on moringa seed extract (Moringa oleifera L.) in coagulation activity done by Aslamiah et al. (2013), indicates that the usage of moringa extract is more effective rather than alum. The moringa seed extract can reduce the amount of turbidity amount by $81 \%$, while alum can only reduce $58 \%$. The addition of moringa seed extract enables the $\mathrm{pH}$ level in the wastewa- ter to be within normal range. On the other hand, the addition of alum may cause acidification of water (lowering the amount of $\mathrm{pH}$ ).

Many studies regarding natural coagulant Moringa oleifera (MO) only focused on its turbidity removal and wastewater suspended solids within the initial $\mathrm{pH}$ of $6-8$. There is still not enough information about the effectiveness of moringa seed extract used as flocculants to lower the amount of wastewater suspended solids under alkaline conditions $(\mathrm{pH}>9)$.

The main purpose of this research is to evaluate the capability and effectiveness of Moringa oleifera extract as flocculants to remove wastewater suspended solids in herbal pharmaceutical industry. The influence of flocculation dosage, coagulant dosage and velocity gradien of flocculation process were studied by determining the percentage of suspended solid removal.

\section{MATERIAL AND METHOD}

This research was done on a laboratory scale using batch system method. The research variable involved the dosage of flocculant Moringa oleifera extract $(\mathrm{ml} / \mathrm{L})$, coagulant dosage $(\mathrm{mg} / \mathrm{L})$ and flocculation gradient velocity $\left(G, \sec ^{-1}\right)$.

\section{Material}

\section{Herbal pharmaceutical industry wastewater}

The wastewater used in this research originally came from the inlet of herbal pharmaceutical industry wastewater treatment process, which was collected over 3 days. During the preservation process, wastewater was being stored at $4^{\circ} \mathrm{C}$.

\section{Extract of Moringa oleifera}

Moringa oleifera plant used in this research was obtained from local collectors in East Java, Indonesia. The part of the plant which was used included the white colored skinless seeds. The dried seeds were processed with coffee grinding mill, then crushed with mortar and sieved, until the size of Moringa powder was 40-60 mesh.

Moringa seeds contains fat by $0.1 \mathrm{gr} / 100 \mathrm{gr}$ ingredients (Fahey, 2005). Fat can damage the protein solvability in water; hence, it has to be eliminated. The process of fat removal on Moringa seeds complies with the work procedure from Susanti et al. (2015) and Hidayat (2009), which gives Hexane solvent to Moringa powder with ra- 
tio 1:4 (b/v). Hexane will dissolve fat and floats when centrifuged at $5000 \mathrm{rpm}$ for 10 minutes at room temperature. The supernatant was disposed of, and the fat-free Moringa sediment was poured into beaker glass, and stirred to evaporate the remaining hexane.

The fat-free Moringa powder was then added with $\mathrm{NaCl}$ solution $1 \mathrm{M}$ to extract the protein on Moringa according to the work procedure done by (Okuda et al. 2001; Sánchez-Martín et al. 2012; Fatehah et al. 2013; Aslamiah et al. 2013; Prihatinningtyas, 2013), which is 5 gr MO powder plus $100 \mathrm{ml} \mathrm{NaCl} 1 \mathrm{M}$ solution and keep being stirred with $100 \mathrm{rpm}$ speed for 1 hour. The physical quality of Moringa oleifera extract filtrate is characterized by $\mathrm{pH} 4.7$, yellow colour, with a distintive odor, and density of $1 \mathrm{~g} / \mathrm{ml}$.

\section{Equipment}

Jar test equipment used included Jar Test Model JT 203/6 with six $1 \mathrm{~L}$ vats, and $\mathrm{pH}$ (pH meter-PG 1800 GEHAKA). A qualitative analysis to reveal the specific surface functional groups on Moringa oleifera extract was performed by Fourier Trasform Infrared (FTIR) transmission spectra using $\mathrm{KBr}$ technique. The analysis was carried out on MAGNA-IR 560, in the wave number of $400-4000 \mathrm{~cm}^{-1}$. The element analysis was conducted by Energy dispersive X-ray spectrometer (EDX) Quantax 75.

\section{Method}

\section{Coagulation - flocculation test}

Coagulation - flocculation test was done by conducting the jar test at various speeds according to variation of conducted treatment research. Flash mixing performed with $\mathrm{G}$ factor $390 \mathrm{sec}^{-1}$ for 1 minute, followed by slow mixing for 9 minutes with $G$ factor variation $50-100 \mathrm{sec}^{-1}$, and settling at room temperature for 30 minutes. Removal of suspended solids was selected as the dependent variable.

\section{Experimental design and data analysis}

The central composite design (CCD), which is one of the important designs of RSM, was selected for the optimization of the parameters. Since different variables are usually expressed in different units and/or have different limits of variation, the importance of their effect on the reponse can only be compared after they are coded (Nourani, 2016). Input variable pointed into a code as $\mathrm{x}=\left(x_{1}, \ldots x_{\mathrm{k}}\right)$. CCD consists of 3 (three) sections comprising eight factorial point (coded to the usual \pm 1 notation), six axial points $( \pm \alpha, 0,0)$, $(0, \pm \alpha, 0)$ and $(0,0, \pm \alpha)$, and six replicates at center points $(0,0,0)$. The number of points in cube portion of design $\left(\mathrm{N}_{\mathrm{f}}\right)$ affects the $\alpha$ value, which is given in Eq. 1:

$$
\alpha=\left(\mathrm{N}_{\mathrm{f}}\right)^{1 / 4}
$$

where: $N_{f}=2^{k}$,

$k$ is the number of factor. According to Eq.1,

$\alpha$ is equal to $\left(2^{3}\right)^{1 / 4}=1.682$. The relationship between the code and actual values of factors and range of levels of variables tested in CCD are given in Table 1.

\section{RESULTS AND DISCUSSION}

\section{Wastewater of herbal pharmaceutical industry}

In this study, the concentration of suspended solids (SS) of herbal pharmaceutical industrial wastewater was $1375 \mathrm{mg} / \mathrm{L}$, average initial pH 9-10 and settling time of sedimentation 30 minutes.

\section{Charateristic of Moringa oleifera extract}

Identification of coagulation function cluster has been measured with FTIR method (Fourier Transform Infra Red). The FTIR method was used to quantitatively identify organic/ inorganic compounds. The final check of spectral cluster from Moringa oleifera active extract was displayed in Figure 1.

Figure 1 shows that specific peak number of Moringa oleifera extract occurs in the wavelength region 3495.26-455.13 $\mathrm{cm}^{-1}$. A board stretching peak at around $3289 \mathrm{~cm}^{-1}$ indicated the presence of $(\mathrm{N}-\mathrm{H})$ group. The weak peak at $1644 \mathrm{~cm}^{-1}$ indicated the presence of $\mathrm{C}=\mathrm{O}$ and $\mathrm{N}-\mathrm{H}_{2}$ group. Another peak at 1448 was the effect of bonding $\mathrm{C}-\mathrm{H}_{3}$ group. The effect of bonding $\mathrm{O}-\mathrm{H}$ group was shown at the peak $1231 \mathrm{~cm}^{-1}$. These results confirmed the spesific peak indicates that MO extract has aliphatic primary amides and primary aliphatic alkohol function cluster (Al-Anizi et al. 2014; Barrado-Moreno et al. 2016; Garde et al. 2017; Nordmark et al. 2016). Amide cluster indicates that flocculant is positively charged, and 
Table 1. The code and actual values of factor and range of variable tested in CCD

\begin{tabular}{|c|c|c|c|c|}
\hline $\begin{array}{c}\text { Code } \\
\left(X_{i}\right)\end{array}$ & $\begin{array}{c}\text { Value of factor } \\
\left(X_{i}\right)\end{array}$ & $\begin{array}{c}\text { Moringa oleifera extract } \\
(\text { flocculant }) \text { dosage } \\
(\mathrm{ml} / \mathrm{L}), X_{1}\end{array}$ & $\begin{array}{c}\text { Alum } \\
(\text { coagulant }) \text { dosage } \\
(\mathrm{mg} / \mathrm{L}), X_{2}\end{array}$ & $\begin{array}{c}\mathrm{G} \text { flocculation } \\
\left(\mathrm{sec}^{-1}\right), X_{3}\end{array}$ \\
\hline$-\alpha$ & $X \operatorname{Xmin}$ & 3.00 & 7.00 & 50 \\
\hline-1 & $\frac{(\alpha-1) X \max +(\alpha+1) X \min }{2 \alpha}$ & 6.45 & 10.00 & 75 \\
\hline 0 & $\frac{X \max +X \min }{2}$ & 11.50 & 12.97 & 90 \\
\hline 1 & $\frac{(\alpha-1) X \min +(\alpha+1) X \max }{2 \alpha}$ & 16.55 & 15.00 & 100 \\
\hline$+\alpha$ & $X \operatorname{Xmax}$ & 20.00 & & \\
\hline
\end{tabular}

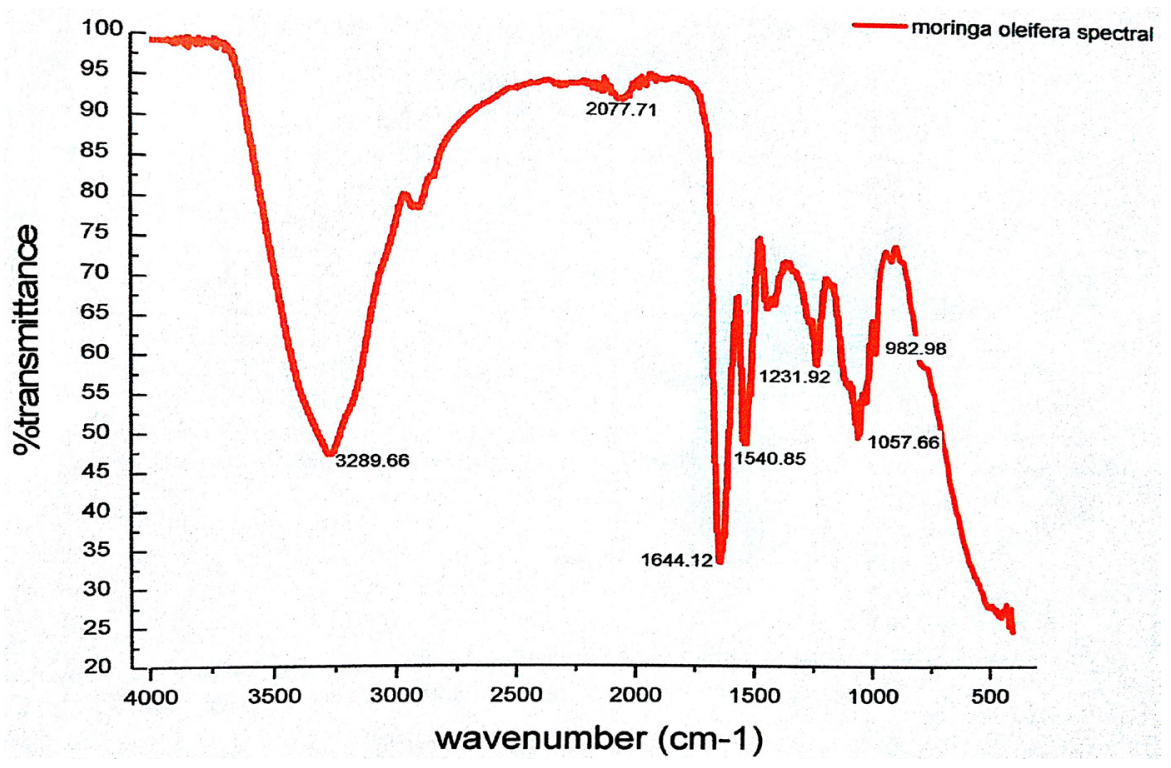

Figure 1. IR spectral of Moringa oleifera extract

hydroxyl cluster is charged negatively. Figure 1 also shows that in Moringa oleifera extract, many polypeptides are found, including polyamide, poly(N-methyl acrylamide), phthalamide polymer, pantothenyl compound (Prihatinningtyas, 2013; De Paula et al. 2014).

Moringa oleifera extract was tested by energy dispersive X-ray spectrometer (EDX) and the results are represented in Figure 2. The presence of alumunium and chloride confirmed that moringa oleifera have the same component as poly-alumunium chloride (PAC)

\section{Modelling and statistical analysis}

The percentages of suspended solid removal from CCD structure were 93.42-99.54\%. These results indicate that concentration of coagulant dosage, flocculant dosage and $G$ flocculation have a significant impact on the removal of suspended solid (Table 2). The adequancy and significance of the quadratic model was justified by the analysis of variance (ANOVA).

The $2^{\text {nd }}$ order polynomial equation was developed to correlate the percentage of suspended solid removal $\left(Y_{\mathrm{SS}}, \%\right)$ as function of coagulant dosage $\left(X_{1}\right)$, flocculant dosage $\left(X_{2}\right)$ and gradient velocity of flocculation $\left(X_{3}\right)$. The following equation is a regression model with experimental results:

$$
\begin{gathered}
Y=99.439+1.0873 \times 1-0.1515 \times 2+ \\
+1.2165 \times 3-1.1050 \times 1^{2}-0.3361 \times 2^{2}- \\
-0.8964 \times 3^{2}+0.276 \times 1 X 2-0.239 \times 1 X 3+ \\
+0.259 \times 2 X 3
\end{gathered}
$$

where: $Y$ is the suspended solid removal efficiency predicted response,

$X_{1}$ the floculant dosage $(\mathrm{mg} / \mathrm{L}), X_{2}$ the coagulant dosage $(\mathrm{ml} / \mathrm{L})$,

$X_{3}$ the gradient velocity of flocculation $\left(\mathrm{sec}^{-1}\right)$. 


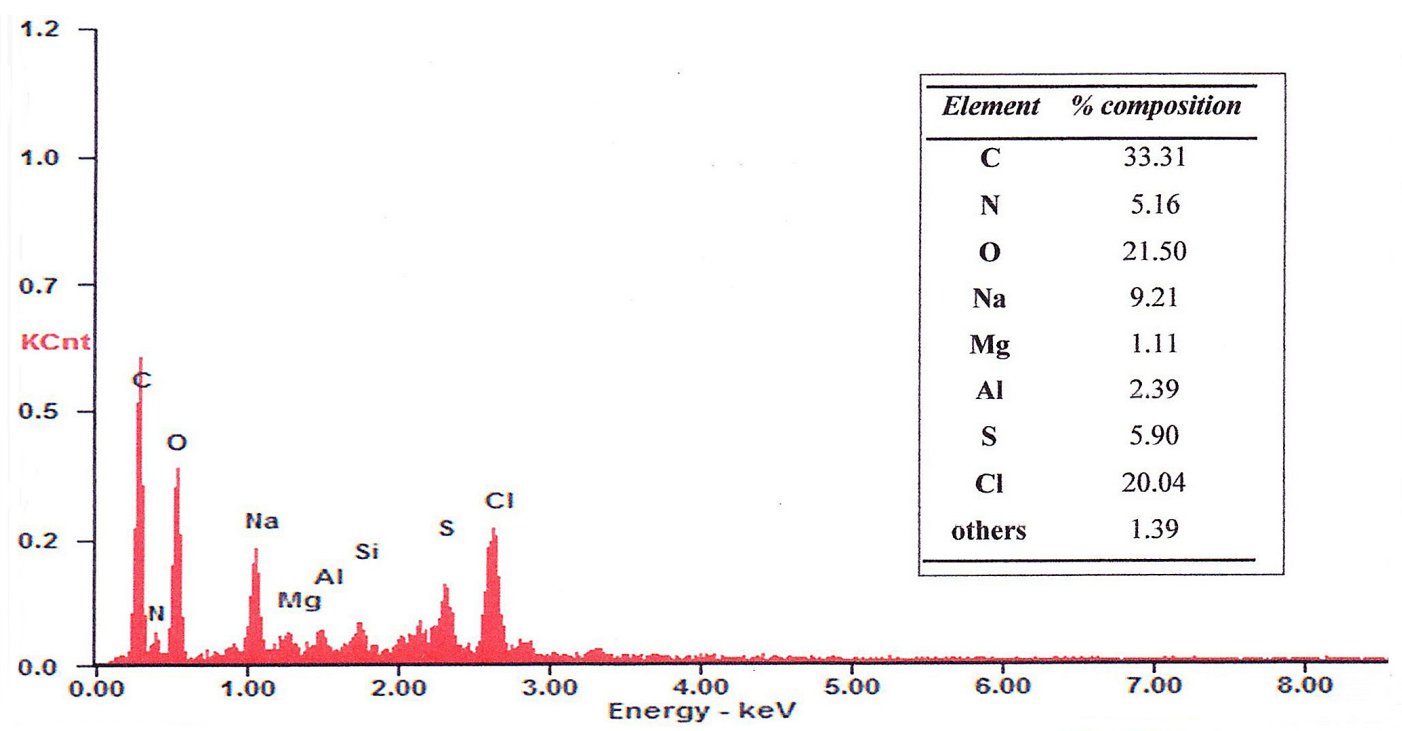

Figure 2. Energy-dispersive X-ray spectroscopy (EDX) analysis

Table 2. Central composite design (CCD) of suspended solid removal (\%)

\begin{tabular}{|c|c|c|c|c|c|c|c|c|c|}
\hline \multirow{2}{*}{ StdOrder } & RunOrder & PtType & Blocks & $\begin{array}{c}\text { Coded value } \\
\text { Roringa } \\
\text { oleifera extract } \\
\text { flocculant) } \\
\text { dosage }\left(X_{1}\right)\end{array}$ & $\begin{array}{c}\text { Alum } \\
\text { (coagulant) } \\
\text { dosage }\left(X_{2}\right)\end{array}$ & $\begin{array}{c}\text { Gradient } \\
\text { velocity of } \\
\text { floculation }\left(X_{3}\right)\end{array}$ & Actual & Predicted & Residual \\
\hline 4 & 1 & 1 & 1 & 1 & 1 & -1 & 97.04 & 97.08 & -0.0367 \\
\hline 13 & 2 & -1 & 1 & 0 & 0 & -1.681 & 95.05 & 94.86 & 0.1928 \\
\hline 17 & 3 & 0 & 1 & 0 & 0 & 0 & 99.54 & 99.44 & 0.1013 \\
\hline 1 & 4 & 1 & 1 & -1 & -1 & -1 & 95.47 & 95.25 & 0.2249 \\
\hline 2 & 5 & 1 & 1 & 1 & -1 & -1 & 97.11 & 97.34 & -0.2347 \\
\hline 20 & 6 & 0 & 1 & 0 & 0 & 0 & 99.33 & 99.44 & -0.1087 \\
\hline 16 & 7 & 0 & 1 & 0 & 0 & 0 & 99.54 & 99.44 & 0.1013 \\
\hline 7 & 8 & 1 & 1 & -1 & 1 & 1 & 97.32 & 97.30 & 0.0199 \\
\hline 14 & 9 & -1 & 1 & 0 & 0 & 1.681 & 99.06 & 98.95 & 0.1109 \\
\hline 15 & 10 & 0 & 1 & 0 & 0 & 0 & 99.31 & 99.44 & -0.1287 \\
\hline 5 & 11 & 1 & 1 & -1 & -1 & 1 & 97.46 & 97.64 & -0.1781 \\
\hline 3 & 12 & 1 & 1 & -1 & 1 & -1 & 93.42 & 93.87 & -0.4520 \\
\hline 19 & 13 & 0 & 1 & 0 & 0 & 0 & 99.32 & 99.44 & -0.1187 \\
\hline 8 & 14 & 1 & 1 & 1 & 1 & 1 & 99.11 & 99.55 & -0.4397 \\
\hline 18 & 15 & 0 & 1 & 0 & 0 & 0 & 99.54 & 99.44 & 0.1013 \\
\hline 11 & 16 & -1 & 1 & 0 & -1.681 & 0 & 98.61 & 98.74 & -0.1329 \\
\hline 10 & 17 & -1 & 1 & 1.681 & 0 & 0 & 98.32 & 98.14 & 0.1782 \\
\hline 9 & 18 & -1 & 1 & -1.681 & 0 & 0 & 94.61 & 94.48 & 0.1255 \\
\hline 12 & 19 & -1 & 1 & 0 & 1.681 & 0 & 98.67 & 98.23 & 0.4366 \\
\hline 6 & 20 & 1 & 1 & 1 & -1 & 1 & 99.02 & 98.78 & 0.2372 \\
\hline
\end{tabular}

Statistical testing of the model was performed with analysis of variance (ANOVA). The results of ANOVA for suspended solid removal are shown in Table 3. The $\mathrm{P}_{\text {value }}$ determines whether $\mathrm{F}_{\text {value }}$ is large enough to indicate statistical significance or lack thereof. The $\mathrm{P}_{\text {value }}$ less than $\alpha$ (or 0.05 ) indicates that the model is significant (Turányi, 2015). Table 3 shown that the quadratic model has a very low probability value $\left(\mathrm{P}_{\text {value }}<0.0000\right)$, it indicates that the model is very significant. Another test procedure that has been done regarding the model feasibility is Lack of Fit test. The statistical hypothesis is suitable regression model (lack of fit is not found) if $\mathrm{P}_{\text {value }}>0.05$. Table 3 shows that lack of fit score has $\mathrm{P}_{\text {value }}=0.108(>0.05)$, thus there is no model gap. $\mathrm{A} \mathrm{R}^{2}$ value greater than $98.53 \%$ 
indicates the aptness of the model (Harfouchi et al. 2016; Teh et al. 2014)

\section{Response surface and contour plots}

Surface plots and its corresponding contour plots are represented in Figure 3. The elliptical shape in the contours shows significant interaction between factors. The ellipse central point in the contour diagram represents the highest predictive value for the response in the selected intervals. The ellipse pattern indicates several interactions between independent variables.

In Figure 3 (a), it is seen that by increasing MO extracts to a certain amount, the percentage of suspended solid removal reaches to maximum and then decreases. This indicates that the coagulant and flocculant disturb the stability of colloidal ionic of wastewater, thus forming flocs that can presipitate. In Figure 3 (a) it can also be seen that suspended solid removal is more dependent on flocculant dosage. Therefore, increasing or decreasing the coagulant dosage (alum) has no influence on the suspended solid removal. The $\mathrm{P}_{\text {value }}$ coagulant dosage $\left(X_{2}\right)$ is $0.148(>0.05)$, indicated that coagulant has an insignificant effect on the suspended solid removal model.

Figure 3 (b) and (c) show that the gradient velocity of flocculation $(G)$ has a significant effect on suspended solid removal. The $G$ values that are too low or too high will decrease the percent- age of removal, although both the alum and $\mathrm{MO}$ extracts are increased. Determining the optimum $G$ value is very important in the suspended solid clarification process. The interaction values of $X_{1} X_{3}(0.051)$ and $X_{2} X_{3}(0.0032)$ showed that the interaction of G-alum and G-MO extracts had a significant effect on the suspended solid removal.

\section{Response optimization of suspended solid removal}

Optimum conditions for the removal of suspended solid process were searched by applying desirability function. As shown in Table 4, the optimum point $(100 \%)$ of decreasing suspended solid quadratic model is at $10.6566 \mathrm{mg} / \mathrm{L}$ alum dosage, $13.8182 \mathrm{ml} / \mathrm{L}$ Moringa oleifera extract dosage, and $G$ flocculation $84.8485 \mathrm{sec}^{-1}$.

\section{Mechanism of flocculation with MO extract}

Wastewater from herbal pharmaceutical industry is a stable and alkaline colloid $(\mathrm{pH}>9)$. Under alkaline conditions, alum cannot work properly; therefore, no charge neutralization in the suspension occurs. Morringa oleifera can function as flocculant because it conceives soluble protein in the water with low molecule (Fahey, 2005). Protein will be positively charged when it is dissolved in the water. Protein will act as positive synthesis substance. The most pos-

Table 3.Analysis of variance for suspended solid removal

\begin{tabular}{|c|c|c|c|c|c|}
\hline Source & Df & Sum of squares & Mean square & F-ratio & P-value \\
\hline Model & 9 & 65.2335 & 7.2482 & 74.59 & 0.000 \\
\hline Linier & 3 & 36.6711 & 12.2237 & 125.80 & 0.000 \\
\hline$x_{1}$ & 1 & 16.1462 & 16.1462 & 166.17 & 0.000 \\
\hline$x_{2}$ & 1 & 0.3135 & 0.3135 & 3.23 & 0.148 \\
\hline$X_{3}$ & 1 & 20.2114 & 20.2114 & 208.00 & 0.000 \\
\hline Square & 3 & 26.9602 & 8.9867 & 92.49 & 0.000 \\
\hline$X_{1}^{*} X_{1}$ & 1 & 17.5980 & 17.5980 & 181.11 & 0.000 \\
\hline$X_{2}^{*} X_{2}$ & 1 & 1.6276 & 1.6276 & 16.75 & 0.002 \\
\hline$X_{3}^{*} X_{3}$ & 1 & 11.5812 & 11.5812 & 119.19 & 0.000 \\
\hline 2-way Interaction & 3 & 1.6021 & 0.5340 & 5.50 & 0.017 \\
\hline$X_{1}^{*} X_{2}$ & 1 & 0.6105 & 0.6105 & 6.28 & 0.031 \\
\hline$X_{1}^{*} X_{3}$ & 1 & 0.4560 & 0.4560 & 4.69 & 0.051 \\
\hline$X_{2}^{*} X_{3}$ & 1 & 0.5356 & 0.5356 & 5.51 & 0.0041 \\
\hline Error & 10 & 0.9717 & 0.0972 & & \\
\hline Lack of fit & 5 & 0.8989 & 0.1798 & 12.35 & 0.108 \\
\hline Pure Error & 5 & 0.0728 & 0.0146 & & \\
\hline Total & 19 & 66.2052 & & & \\
\hline Model Summary & $S$ & $\mathrm{R}^{2}$ & Adj $R^{2}$ & \multicolumn{2}{|c|}{$\mathrm{R}^{2}$ predicted } \\
\hline & 0.311719 & $98.53 \%$ & $97.21 \%$ & \multicolumn{2}{|c|}{$88.64 \%$} \\
\hline
\end{tabular}


a1)

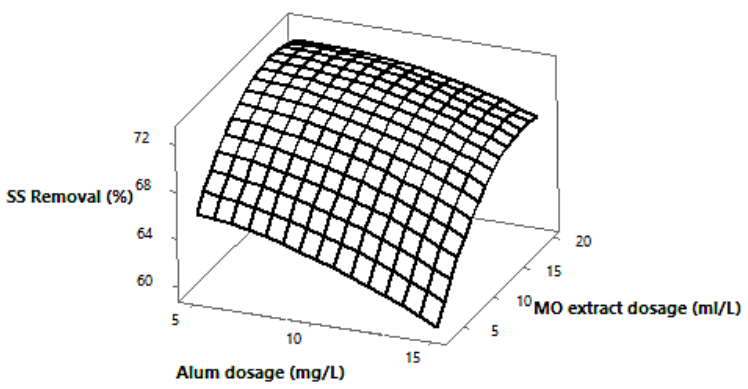

b1)

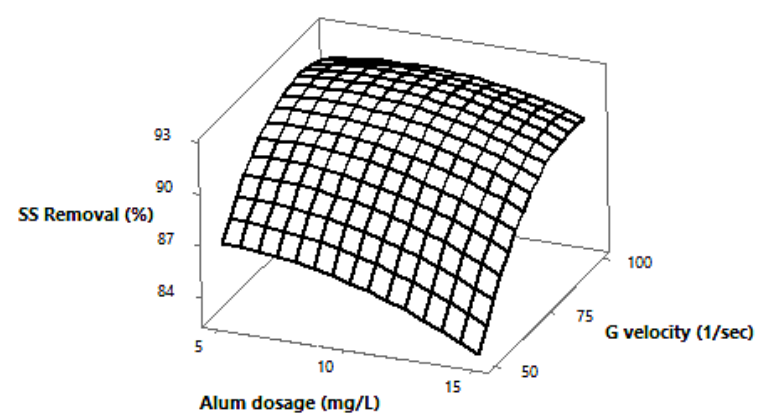

c1)

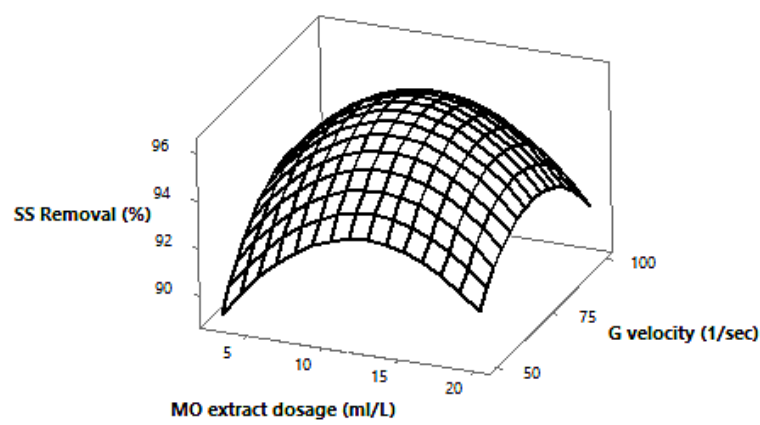

a2)

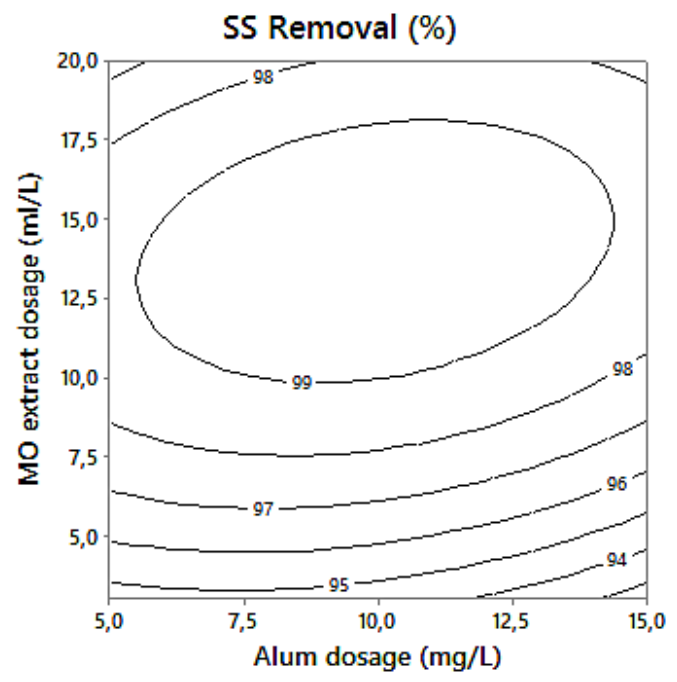

b2)

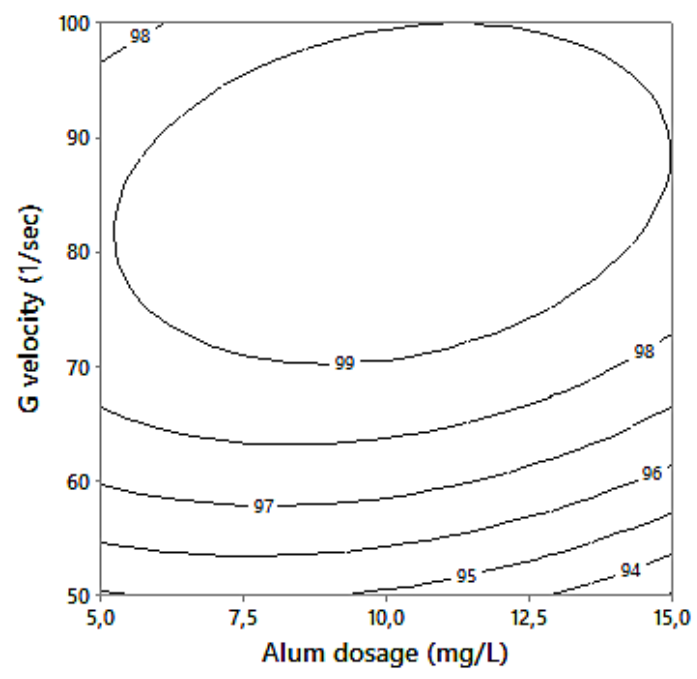

c2)

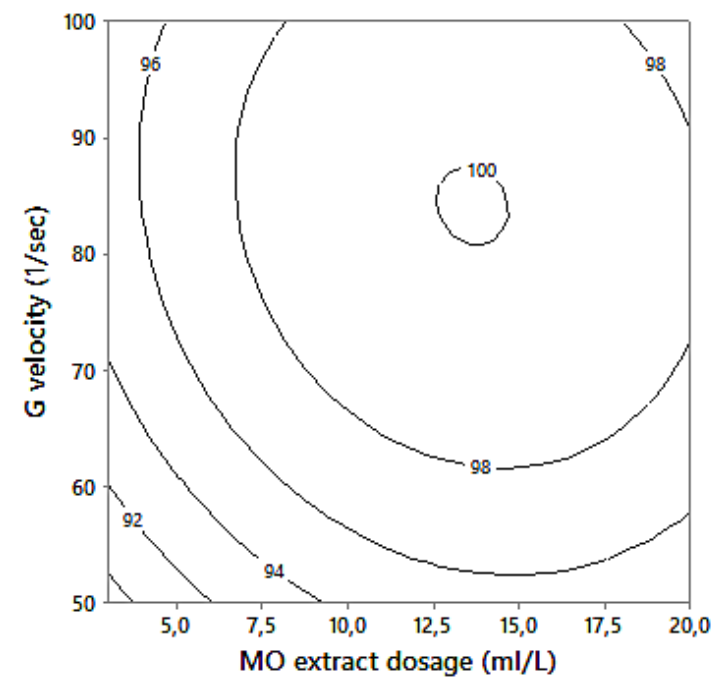

Figure 3. Surface plots and contour plots of suspended solid removal showing the effect of variables, (a) Alum dosage vs MO dosage at $G 75 \mathrm{sec}^{-1}$ (b) Alum dosage vs $G$ velocity at MO dosage $11.5 \mathrm{ml} / \mathrm{L}$ (c) MO dosage vs $G$ velocity at Alum dosage $10 \mathrm{mg} / \mathrm{L}$ 
Table 4. Response optimization of percentae suspended solid removal

\begin{tabular}{|l|c|}
\hline \multicolumn{1}{|c|}{ Parameter } & Results \\
\hline Goal & $\begin{array}{c}\text { maximum response } \\
\text { suspended solid removal } \\
(\%)\end{array}$ \\
\hline Lower & 93.42 \\
\hline Target & 99.54 \\
\hline Weight & 1 \\
\hline Importance & 1 \\
\hline Solution: Alum dosage (mg/L) & 10.6566 \\
\hline MO dosage (ml/L) & 13.8182 \\
\hline G velocity (sec-1) & 84.8485 \\
\hline SS removal (\%), Fit & 100 \\
\hline SS removal $(\%)$, SE Fit & 0.127 \\
\hline
\end{tabular}

sible mechanism that occured on the moringa flocculation process is adsorption as well as voltage neutralization or adsorption and unstable particle bonds. It is hard to determine which mechanism possibly occurs, they are simultaneous (De Paula et al., 2014).

The positive charge released into the solution will react with the hydroxyl ions in the suspension, so the $\mathrm{pH}$ of the suspension becomes neutral. On the other hand, the negative charge will react with the metal in colloids, to form heavier flocs which are able to precipitate (Hendrawati et al. 2016; Jiang, 2015; Barrado-Moreno et al. 2016).

\section{CONCLUSION}

Flocculant active cluster from Moringa oleifera extract consittute Aliphatic Primary Amides and Primary Aliphatic Alcohol. The amide cluster shows that polyelectrolyte flocculant is positively charged, while polyelectrolyte hydroxyl cluster is charged negatively. The mechanism that occurs during the MO flocculant process is adsorption and voltage neutralization or adsorption and unstable particles bond.

The test results of analysis response surface showed that the variables of flocculant dosage and the flocculation velocity gradient $(\mathrm{G})$ exert a huge impact on the amount of suspended solid removal, compared with the coagulant dosage. The model generated from the response analysis is a quadratic model. The optimum point of the removal suspended solid quadratic model is $10.6566 \mathrm{mg} / \mathrm{L}$ alum dosage, $13.8185 \mathrm{ml} / \mathrm{L}$ Moringa oleifera extract dosage, and $G$ flocculation velocity of $84.8485 \mathrm{sec}^{-1}$.

\section{REFERENCES}

1. Al-Anizi, A.A., Hellyer, M.T., \& Zhang, D., 2014. Toxicity assessment and modelling of Moringa oleifera seeds in water purification by whole cell bioreporter. Water Research, 56.

2. Amante, B., López-Grimau, V., \& Smith, T., 2016. Valuation of oil extraction residue from Moringa oleifera seeds for water purification in Burkina Faso. Desalination and Water Treatment, 57(6).

3. Aslamiah, S.S., Yulianti, E., \& Jannah, A., 2013. Coagulation Activity of Kelor Seed Extract (Moringa oleifera L.) in $\mathrm{NaCl}$ Solution to Liquid Waste PT. SIER PIER Pasuruan. Alchemy, 2(3), 178-183. http://ejournal.uin-malang.ac.id/index.php/Kimia/ article/view/2891.

4. Baptista, A.T.A., Coldebella, P.F., Cardines, P.H.F., Gomes, R.G., Vieira, M.F., Bergamasco, R., \& Vieira, A.M.S., 2015. Coagulation-flocculation process with ultrafiltered saline extract of moringa oleifera for the treatment of surface water. Chemical Engineering Journal, 276.

5. Baptista, A.T.A., Silva, M.O., Gomes, R.G., Bergamasco, R., Vieira, M.F., \& Vieira, A.M.S., 2017. Protein fractionation of seeds of Moringa oleifera lam and its application in superficial water treatment. Separation and Purification Technology, 180.

6. Barrado-Moreno, M.M., Beltran-Heredia, J., \& Martín-Gallardo, J., 2016. Microalgae removal with Moringa oleifera. Toxicon, 110.

7. Bhuptawat, H., Folkard, G.K., \& Chaudhari, S., 2007. Innovative physico-chemical treatment of wastewater incorporating Moringa oleifera seed coagulant. Journal of Hazardous Materials, 142(1-2), 477-482.

8. Bratby, J., 2016. Coagulation and flocculation in water and wastewater treatment. Third Edition, IWA Publishing, London.

9. Dassanayake, K.B., Jayasinghe, G.Y., Surapaneni, A., \& Hetherington, C., 2015. A review on alum sludge reuse with special reference to agricultural applications and future challenges. Waste Management, 38.

10. De Paula, H.M., De Oliveira Ilha, M.S., \& Andrade, L.S., 2014. Concrete plant wastewater treatment process by coagulation combining aluminum sulfate and Moringa oleifera powder. Journal of Cleaner Production, 76.

11. Fahey, J., 2005. Moringa oleifera: A Review of the Medical Evidence for Its Nutritional, Therapeutic, and Prophylactic Properties. Part 1. Trees for Life Journal, 1-15.

12. Fatehah, M.O., Hossain, S., \& Teng, T.T., 2013. Semiconductor Wastewater Treatment Using Tapioca Starch as a Natural Coagulant. Journal of Water Resource and Protection, 5(11), 1018-1026. http://www.scirp.org/journal/PaperInformation. aspx?PaperID=40064\&\#abstract. 
13. Garde, W.K., Buchberger, S.G., Wendell, D., \& Kupferle, M.J., 2017. Application of Moringa Oleifera seed extract to treat coffee fermentation wastewater. Journal of Hazardous Materials, 329.

14. Ghebremichael, K.A., Gunaratna, K.R., Henriksson, H., Brumer, H., \& Dalhammar, G., 2005. A simple purification and activity assay of the coagulant protein from Moringa oleifera seed. Water Research, 39(11), 2338-2344.

15. Harfouchi, H., Hank, D., \& Hellal, A., 2016. Response surface methodology for the elimination of humic substances from water by coagulation using powdered Saddled sea bream scale as coagulantaid. Process Safety and Environmental Protection, 99, 216-226. http://dx.doi.org/10.1016/j. psep.2015.10.019.

16. Hendrawati, Yuliastri, I.R., Nurhasni, Rohaeti, E., Effendi, H., \& Darusman, L.K., 2016. The use of Moringa Oleifera Seed Powder as Coagulant to Improve the Quality of Wastewater and Ground Water. IOP Conference Series: Earth and Environmental Science, 31.

17. Hidayat, S., 2009. Protein Biji Kelor Sebagai Bahan Aktif Penjernihan Air (Kelor Seeds Proteins As Water Purification Agent). Protein Biji Kelor Sebagai Bahan Aktiv Penjernihan Air (Kelor Seeds roteins as Water Purification Agent), 2, 1-69.

18. Irfan, M., Butt, T., Imtiaz, N., Abbas, N., Khan, R.A., \& Shafique, A., 2017. The removal of COD, TSS and colour of black liquor by coagulationflocculation process at optimized $\mathrm{pH}$, settling and dosing rate. Arabian Journal of Chemistry, 10.

19. Jiang, J.Q., 2015. The role of coagulation in water treatment. Current Opinion in Chemical Engineering, 8, 36-44.

20. Krzemińska, D., Neczaj, E., \& Borowski, G., 2015. Advanced oxidation processes for food industrial wastewater decontamination. Journal of Ecological Engineering, 16(2), 61-71

21. Lee, C.S., Robinson, J., \& Chong, M.F., 2014. A review on application of flocculants in wastewater treatment. Process Safety and Environmental Protection, 92, 489-508.

22. Nordmark, B.A., Przybycien, T.M., \& Tilton, R.D., 2016. Comparative coagulation performance study of Moringa oleifera cationic protein fractions with varying water hardness. Journal of Environmental Chemical Engineering, 4(4).

23. Nourani, M., Baghdadi, M., Javan, M., \& Bidhendi, G.N., 2016. Production of a biodegradable flocculant from cotton and evaluation of its performance in coagulation-flocculation of kaolin clay suspension: Optimization through response surface methodology (RSM). Journal of Environmental Chemical Engineering, 4(2), hal.1996-2003. http://dx.doi.org/10.1016/j.jece.2016.03.028.

24. Okuda, T., Baes, A.U., Nishijima, W., \& Okada, M., 2001. Coagulation Mechanism of Salt Solution-Extracted Active Component in Moringa ole- ifera Seeds. Water Research, 35(3), 830-834.

25. Pavankumar, A.R., Norén, J., Singh, L., \& Chandappa Gowda, N.K., 2014. Scaling-up the production of recombinant Moringa oleifera coagulant protein for large-scale water treatment applications. RSC Advances, 4(14).

26. Prihatinningtyas, 2013. Natural Coagulant Application from Corn Flour In Clean Water Treatment. Jurnal Teknosains, 2(2), 1-26.

27. Sánchez-Martín, J., Beltrán-Heredia, J., \& Peres, J.A., 2012. Improvement of the flocculation process in water treatment by using Moringa oleifera seeds extract. Brazilian Journal of Chemical Engineering, 29(3), 495-501. http://www.scielo.br/ scielo.php?script $=$ sci_arttext\&pid $=$ S0104-66322 $012000300006 \& \operatorname{lng}=$ en\&nrm=iso\&tlng $=$ en $\quad[$ Accessed 24 Agustus 2016].

28. Santos, A.F.S., Matos, M., Sousa, Â., Costa, C., Nogueira, R., Teixeira, J.A., Paiva, P.M.G., Parpot, P., Coelho, L.C.B.B., \& Brito, A.G., 2016. Removal of tetracycline from contaminated water by Moringa oleifera seed preparations. Environmental Technology (United Kingdom), 37(6).

29. Shak, K.P.Y., \& Wu, T.Y., 2014. Coagulation-flocculation treatment of high-strength agro-industrial wastewater using natural Cassia obtusifolia seed gum: Treatment efficiencies and flocs characterization. Chemical Engineering Journal, 256, 293-305. http://dx.doi.org/10.1016/j.cej.2014.06.093.

30. Subramonian, W., Wu, T.Y., \& Chai, S.P., 2014. A comprehensive study on coagulant performance and floc characterization of natural Cassia obtusifolia seed gum in treatment of raw pulp and paper mill effluent. Industrial Crops and Products, 61.

31. Suopajärvi, T., Liimatainen, H., Hormi, O., \& Niinimäki, J., 2013. Coagulation-flocculation treatment of municipal wastewater based on anionized nanocelluloses. Chemical Engineering Journal, 231.

32. Susanti, E., Ciptati, Ratnawati, R., Aulanni'am, \& Rudijanto, A., 2015. Qualitative analysis of catechins from green tea GMB-4 clone using HPLC and LC-MS/MS. Asian Pacific Journal of Tropical Biomedicine, 5(12), 1046-1050. http://dx.doi. org/10.1016/j.apjtb.2015.09.013.

33. Teh, C.Y., Wu, T.Y., \& Juan, J.C., 2014. Optimization of agro-industrial wastewater treatment using unmodified rice starch as a natural coagulant. Industrial Crops and Products, 56.

34. Turányi, T., \& Tomlin, A.S., 2015. Analysis of Kinetic Reaction Mechanisms. Tersedia dihttps://books. google.com/books?id=11sEBgAAQBAJ\&pgis=1.

35. Wang, F.-H., Hao, H.-T., Sun, R., Li, S., Han, R., Papelis, C., \& Zhang, Y., 2014. Bench-scale and pilot-scale evaluation of coagulation pre-treatment for wastewater reused by reverse osmosis in a petrochemical circulating cooling water system. Desalination, 335(1), 64-69. Tersedia dihttp:/www.sciencedirect.com/science/article/pii/ S0011916413005900. 